\title{
Conservation genetics of the annual hemiparasitic plant Melampyrum sylvaticum (Orobanchaceae) in the UK and Scandinavia
}

\author{
Rhiannon J. Crichton ${ }^{1,2,3} \cdot$ Sarah E. Dalrymple ${ }^{2,4} \cdot$ Sarah J. Woodin $^{2}$ • \\ Peter M. Hollingsworth ${ }^{1}$
}

Received: 10 November 2014/ Accepted: 17 December 2015/Published online: 18 January 2016

(C) The Author(s) 2016. This article is published with open access at Springerlink.com

\begin{abstract}
Melampyrum sylvaticum is an endangered annual hemiparasitic plant that is found in only 19 small and isolated populations in the United Kingdom (UK). To evaluate the genetic consequences of this patchy distribution we compared levels of diversity, inbreeding and differentiation from ten populations from the UK with eight relatively large populations from Sweden and Norway where the species is more continuously distributed. We demonstrate that in both the UK and Scandinavia, the species is highly inbreeding (global $F_{\text {IS }}=0.899$ ). Levels of population differentiation were high $\left(F^{\prime}{ }_{\mathrm{ST}}=0.892\right)$ and significantly higher amongst UK populations $\left(F_{\text {ST }}=\right.$ $0.949)$ than Scandinavian populations $\left(F^{\prime}{ }_{\mathrm{ST}}=0.762\right.$; $\mathrm{P}<0.01)$. The isolated populations in the UK have, on average, lower genetic diversity (allelic richness, proportion of loci that are polymorphic, gene diversity) than Scandinavian populations, and this diversity difference is associated with the smaller census size and population area of UK populations. From a conservation perspective, the naturally inbreeding nature of the species may buffer the species against immediate effects of inbreeding depression, but the markedly lower levels of genetic diversity in UK
\end{abstract}

Electronic supplementary material The online version of this article (doi:10.1007/s10592-015-0803-4) contains supplementary material, which is available to authorized users.

Rhiannon J. Crichton

rhiannon.crichton@gmail.com

1 Royal Botanic Garden Edinburgh, Edinburgh EH3 5LR, UK

2 Institute of Biological and Environmental Sciences, University of Aberdeen, Aberdeen AB24 2TZ, UK

3 Bioversity International, 34980 Montpellier, France

4 School of Natural Sciences and Psychology, Liverpool John Moores University, Liverpool L3 3AF, UK populations may represent a genetic constraint to evolutionary change. In addition, the high levels of population differentiation suggest that gene flow among populations will not be effective at replenishing lost variation. We thus recommend supporting in situ conservation management with ex situ populations and human-mediated seed dispersal among selected populations in the UK.

Keywords Habitat fragmentation - Inbreeding · Microsatellite $\cdot$ Scotland $\cdot$ UKBAP

\section{Introduction}

Small populations in discrete habitat fragments have a greater risk of extinction than larger populations in more continuous habitats (Matthies et al. 2004; O'Grady et al. 2004). This is due to demographic and environmental stochasticities (Lande 1988), the occurrence of edge effects over a greater proportion of the habitat area (Murcia 1995) and resultant changes to species composition and to the interactions between species (Lovejoy et al. 1986; Wotton and Kelly 2011). There are also complex interactions between small population size, genetic diversity and individual fitness (Spielman et al. 2004; Aguilar et al. 2006; Aguilar et al. 2008).

The consequences of small population sizes and isolation on within-population genetic diversity is well understood (reviewed in Schaal and Leverich 1996; Young et al. 1996; Aguilar et al. 2008) and small and isolated populations typically contain less genetic diversity than larger connected populations. Over time, individuals in small, isolated populations will become more homozygous because of the low amounts of available genetic diversity 
within the population and increased inbreeding (Frankham et al. 2002).

The consequence of reduced genetic diversity and increased homozygosity on individual fitness is complex and depends in part on a species' life-history traits (Hamrick and Godt 1996; Bekker and Kwak 2005; Aguilar et al. 2006; Duminil et al. 2007). For species that are obligate outcrossers, this may result in inbreeding depression (Nason and Ellstrand 1995; Charlesworth and Willis 2009; Teixeira et al. 2009; Jolivet et al. 2013). Reduced fitness of individuals in small populations can act to further reduce the population size, creating a positive feedback loop that has been termed an 'extinction vortex' (Gilpin and Soulé 1986). For species that are highly selfing and thus naturally highly homozygous, low genetic diversity and high homozygosity is expected to have lesser impact on inbreeding depression because of the prior purging of deleterious alleles (Husband and Schemske 1996; Byers and Waller 1999; but see Busch 2005; Michalski and Durka 2007; Rouselle et al. 2011). However, even in naturally inbreeding species, low levels of genetic diversity can act as a constraint on evolutionary potential (Neaves et al. 2013).

Melampyrum sylvaticum L. (small cow-wheat), is a summer annual hemiparasitic plant whose distribution in the United Kingdom (UK) consists of a series of small and isolated populations. It was once widely distributed across upland areas but is now known from only 19 populations, all located in Scotland (Dalrymple 2007). The extant populations have low census sizes (18-8000 plants, most with $<100$ individuals), cover small areas $\left(3-150 \mathrm{~m}^{2}\right)$, and occur within discrete habitat fragments that are bordered by unsuitable, anthropogenically-influenced habitat. A further six populations are known to have gone extinct in the UK since 2004 (Dalrymple 2007; Crichton et al. 2012). The causes of population decline are believed to be habitat loss and degradation over long time scales, over-grazing (Rich et al. 1998; Dalrymple 2007), over-collecting and gradual climate change (Tennant 2008). In addition, the species is presumed to be dispersal limited and so unable to recover well from reductions in population area and/or census size (Dalrymple 2006). Because of this relatively recent and rapid decline in abundance in the UK, M. sylvaticum is IUCN red-listed as 'endangered' (Cheffings and Farrell 2005), designated by the UK government as a Biodiversity Action Plan (UKBAP) species (UK Biodiversity Group 1999) and designated by the Scottish government as a Species Action Framework (SAF) species (Scottish Natural Heritage 2007).

Conservation actions to date include the monitoring of extant populations, a species recovery plan involving a series of seed translocations into new sites (Dalrymple 2006; Dalrymple and Broome 2010), and localised population expansions (Andy Scobie, pers. comm., Cairngorms Rare Plants Project, 2012). Whilst much is known about the biology of M. sylvaticum (e.g. Dalrymple 2006; Dalrymple 2007; Těšitel 2007; Těšitel et al. 2010), a serious impediment to designing an appropriate conservation management plan for the species in the UK is a lack of knowledge regarding the species' breeding system and the risks of inbreeding or outbreeding depression; and the amount and distribution of genetic diversity and functional phenotypic diversity within and between populations (Hufford and Mazer 2003; Edmands 2007; Kramer and Havens 2009).

To better inform conservation management plans for $M$. sylvaticum we used nuclear microsatellite markers on a range of population sizes from isolated to more continuous habitats in the UK, Sweden and Norway to infer (1) the breeding system, and to assess (2) the amount of withinpopulation genetic diversity, (3) the relationship between within-population genetic diversity and the area covered by the population, (4) the genetic differentiation between populations, and (5) the relationship between genetic differentiation and geographic distance.

\section{Materials and methods}

\section{Study species}

Melampyrum sylvaticum (Orobanchaceae) is a diploid $(2 \mathrm{n}=18)$ non-clonal, generalist-hemiparasitic therophyte (summer annual) (Dalrymple 2007). It grows as an understory herb in open deciduous and coniferous woodlands, distributed across temperate European mountain ranges and across the Scandinavian and Russian boreal zone (Soó and Webb 1972; Dalrymple 2007). The flower corolla is small (8-12 mm long, Dalrymple 2007), zygomorphic and a golden-yellow colour. It is not known which species act as pollinators for M. sylvaticum, although bees (Hymenoptera) have been suggested as the yellow zygomorphic flowers are known to be attractive to them (Rumsey 1994). Melampyrum sylvaticum is self-compatible and able to set seed without insect visitation, as demonstrated by flower-bagging experiments (Molau 1993; Dalrymple 2006). A mature fruit contains 1-4 large seeds with an elaiosome. Because of their large size, dispersal of $M$. sylvaticum seeds is primarily by gravity and secondarily by ants, resulting in predominantly highly restricted short-distance dispersal around the maternal plant (Dalrymple 2007).

\section{Sampling}

Ten small isolated $M$. sylvaticum populations in Scotland ('UK') were sampled in either July 2008 or July 2009, representing the range of census sizes, area sizes and 
geographical spread of the species in the UK (Table 1). A further eight populations from the Abisko region of northern Sweden, the Sweden-Norway border, and the Lofoten Islands of Norway ('Scandinavia') were sampled in July 2008. These populations were large and located within relatively undisturbed woodland habitat. The Scandinavian sampling extended from the Abisko region to the Lofoten Islands in order to replicate the distances between populations sampled in the UK (population-pairwise geographic distances: UK: $\operatorname{minimum}=1.09 \mathrm{~km}$, average $=75.74 \mathrm{~km}$, maximum $=134.92 \mathrm{~km}$; Scandinavia: minimum $=2.45 \mathrm{~km}$, average $=57.70 \mathrm{~km}$, maximum $=$ $146.24 \mathrm{~km})$.

Sampling within a population involved identifying the population boundaries and sampling up to 30 individuals evenly across the area covered by the population. In the $\mathrm{UK}$, the discrete nature of the populations made this relatively straightforward. In the large Scandinavian populations, the population boundaries are more diffuse and sampling was undertaken in areas where the species cover was continuous. Leaf material was collected into plastic zip-lock bags containing silica gel. The sampling area was calculated in two ways. First, sampled plants were individually mapped (to transects in five UK populations and by GPS in all Scandinavian populations) and the area between the perimeter plants (the 'convex hull') was calculated in R (R Core Development Team 2010) using the 'Spatstat' package (Baddeley and Turner 2005). Second, for five UK populations the area of sampling was estimated using Ordinance Survey maps and Google Earth. A population census was conducted at the time of sampling. For the large Scandinavian populations, the census size was estimated as being between 2000 and 5000, 5000 and 10,000 , or more than 10,000 plants (Table 1 ).

\section{DNA extraction and genotyping}

DNA was extracted from silica gel stored leaf material using the CTAB method (Doyle and Doyle 1990) and genotyped using seven polymorphic microsatellite loci: MsU21, MsV32, MsH14, MsQ84, MsT12, MsO66, and MsJ32 (Crichton et al. 2012b). The forward primers were tagged at the beginning of their sequence with an M13 sequence ( $5^{\prime}$ CACGACGTTGTAAAACGAC- $3^{\prime}$ ) and PCR reactions were performed in $10-\mu \mathrm{L}$ volumes using the protocol: $1 \times$ buffer (Bioline, London, UK), $2.5 \mathrm{mM} \mathrm{MgCl}_{2}, 0.2 \mathrm{mM}$ dNTPs, $0.1 \mu \mathrm{M}$ fluorescently labelled M13 primer (5'CACGACGTTGTAAAACGAC-3'; 6-FAM, VIC, PET, NED), $0.05 \mu \mathrm{M}$ M13 tagged forward microsatellite primer, $0.1 \mu \mathrm{M}$ reverse microsatellite primer, 0.05U taq (Bioline, London, UK) and $1 \mu \mathrm{L}$ of unquantified DNA. The PCR program cycled through: $1 \times 94{ }^{\circ} \mathrm{C} 4 \mathrm{~min}$; 30 cycles of $94{ }^{\circ} \mathrm{C} 30 \mathrm{~s}, 58.5{ }^{\circ} \mathrm{C} 30 \mathrm{~s}, 72{ }^{\circ} \mathrm{C} 30 \mathrm{~s} ; 1 \times 72{ }^{\circ} \mathrm{C} 20 \mathrm{~min}$. $1 \mu \mathrm{l}$ PCR product of each of the four primer-dye combinations per sample was added to $30 \mu \mathrm{l}$ distilled water. $1 \mu \mathrm{l}$ of this mixture was then added to $9 \mu$ formamide including LIZ-500 (Applied Biosystems, Foster City, CA) as internal size standard and run on a $3730 \mathrm{ABI}$ automated sequencer at
Table 1 Sampled populations of Melampyrum sylvaticum in the UK and Scandinavia

\begin{tabular}{llllll}
\hline Population & Abbreviation & Latitude $(\mathrm{N})$ & Longitude $(\mathrm{W})$ & Area $\left(\mathrm{m}^{2}\right)$ & Census size \\
\hline UK & & & & & \\
Aberfeldy & $\mathrm{AB}$ & $56^{\circ} 36^{\prime}$ & $3^{\circ} 52^{\prime}$ & 28 & 1700 \\
Glen Tilt & $\mathrm{GT}$ & $56^{\circ} 47^{\prime}$ & $3^{\circ} 49^{\prime}$ & 10 & 8000 \\
Keltneyburn & $\mathrm{KB}$ & $56^{\circ} 37^{\prime}$ & $4^{\circ} 00^{\prime}$ & 3 & 150 \\
Lismore & $\mathrm{LS}$ & $56^{\circ} 32^{\prime}$ & $5^{\circ} 28^{\prime}$ & 8 & 85 \\
Corriefeol & $\mathrm{CR}$ & $57^{\circ} 30^{\prime}$ & $4^{\circ} 59^{\prime}$ & 5 & 30 \\
Eiridh & $\mathrm{ER}$ & $57^{\circ} 12^{\prime}$ & $5^{\circ} 12^{\prime}$ & 50 & 1200 \\
Athair & $\mathrm{AT}$ & $57^{\circ} 12^{\prime}$ & $5^{\circ} 11^{\prime}$ & 5 & 210 \\
Mar & $\mathrm{Mar}$ & $57^{\circ} 04^{\prime}$ & $3^{\circ} 35^{\prime}$ & 10 & 100 \\
River Nairn Viaduct & $\mathrm{RNV}$ & $57^{\circ} 46^{\prime}$ & $4^{\circ} 37^{\prime}$ & 5 & 40 \\
Loch Ossian & $\mathrm{LO}$ & $56^{\circ} 46^{\prime}$ & $4^{\circ} 37^{\prime}$ & 64 & 1500 \\
Scandinavia & & & & & \\
Marmorbrottet & $\mathrm{MR}$ & $68^{\circ} 20^{\prime}$ & $18^{\circ} 46^{\prime}$ & 133 & $5000-10,000$ \\
Rihtongira & $\mathrm{RH}$ & $68^{\circ} 21^{\prime}$ & $18^{\circ} 45^{\prime}$ & 381 & $>10,000$ \\
Jieprinkiedde & $\mathrm{JD}$ & $68^{\circ} 27^{\prime}$ & $18^{\circ} 51^{\prime}$ & 150 & $5000-10,000$ \\
Stenbacken & $\mathrm{ST}$ & $68^{\circ} 14^{\prime}$ & $19^{\circ} 34^{\prime}$ & 69 & $2000-5000$ \\
Karsevagge & $\mathrm{KR}$ & $68^{\circ} 20^{\prime}$ & $18^{\circ} 41^{\prime}$ & 125 & $5000-10,000$ \\
Riksgransen & $\mathrm{RK}$ & $68^{\circ} 26^{\prime}$ & $18^{\circ} 9^{\prime}$ & 96 & $2000-5000$ \\
Skanland & $\mathrm{SK}$ & $68^{\circ} 38^{\prime}$ & $16^{\circ} 42^{\prime}$ & 102 & $5000-10,000$ \\
Fiskoy & FS & $68^{\circ} 29^{\prime}$ & $16^{\circ} 4^{\prime}$ & 131 & $5000-10,000$ \\
\hline
\end{tabular}


the Genepool facility in Edinburgh, UK. Peaks were scored manually using GeneMapper software v 3.7 (Applied Biosystems, Foster City, CA). Genotyping was repeated on all samples which did not work or where scoring was ambiguous.

Null alleles were inferred by consistent non-amplification of a sample using a primer pair for a given locus, despite reliable amplification of the same sample when using primer pairs for other loci. Population-wide null alleles were present in locus MsT12 for all Scandinavian populations and the UK population GT, and in locus MsJ32 for the UK population GT. Occasional null alleles present in locus MsH14 in the UK population AB were treated as missing data.

\section{Genetic diversity}

The total number of alleles per population $\left(A_{\mathrm{N}}\right)$, allelic richness $\left(A_{\mathrm{R}}\right)$ (the mean number of alleles per locus, with the smallest population [CR, $\mathrm{n}=11]$ removed and so rarefied to the next smallest sample size of 24 individuals), gene diversity $\left(H_{\mathrm{E}}\right)$, the observed heterozygosity $\left(H_{\mathrm{O}}\right)$ and the inbreeding coefficient $\left(F_{\text {IS }}\right)$ were calculated using FSTAT v. 2.9.3.2 (Goudet 1995). The significance of $F_{\text {IS }}$ from zero was calculated by permuting alleles among the individuals within a population (1000 replications). The proportion of loci that are polymorphic $(P)$ and the number of private alleles $\left(A_{\mathrm{P}}\right)$ were calculated using GDA (Lewis and Zaykin 2001). The number of unique multilocus genotypes within a population was calculated on samples with no missing data using GENALEX v. 6.2 (Peakall and Smouse 2006) and transformed into the proportion of distinguishable genotypes $\left(P_{\mathrm{D}}\right)$ by dividing the number of unique multi-locus genotypes by the number of samples used. The significance of the regional difference between $A_{\mathrm{R}}$ (with CR population removed), $H_{\mathrm{E}}, H_{\mathrm{O}}$, and $F_{\mathrm{IS}}$ was calculated in FSTAT using two-way randomisation tests (1000 replications) with all the UK populations in Group 1 and all the Scandinavian populations in Group 2. The significance of the regional difference between $P, A_{\mathrm{N}}, A_{\mathrm{P}}$, and $P_{\mathrm{D}}$ were calculated by performing an unpaired Welch's $t$ test in $\mathrm{R}$ on the population-level values, between the two regions. Tests for association between the genetic diversity parameters of $A_{\mathrm{R}}$ and $H_{\mathrm{E}}$ with the sampling area $\left(\mathrm{m}^{2}\right)$ were calculated by performing a Pearson's product moment correlation coefficient in $\mathrm{R}$.

\section{Genetic structure}

Population genetic differentiation was calculated using three parameters. $F_{\text {ST }}$ (Weir and Cockerham 1984) and standardised $F^{\prime}$ ST (Hedrick 2005) were calculated using FSTAT and RECODEDATA (Meirmans 2006), without assuming Hardy-Weinberg equilibrium, by permuting genotypes among populations with 1000 replications. The significance of regional differences was performed by performing a between group comparison in FSTAT, using a two-way randomisation test (1000 replications). $D_{\mathrm{EST}}$, which relies on allelic differentiation rather than heterozygosity (Jost 2008), was calculated using SMOGD with 1000 bootstrap replications (Crawford 2010). The significance of the difference in $D_{\text {EST }}$ values between populations in the UK and Scandinavia was calculated by performing an unpaired Welch's t-test on the $D_{\text {EST }}$ values of each of the five loci in each region.

To assess whether populations show an isolation-bydistance (IBD) pattern of genetic relatedness, Mantel tests were performed in GENALEX separately on populations within the UK and populations within Scandinavia using the linearised population-pairwise $D_{\text {EST }}$ against populationpairwise linear geographic distance. Population-pairwise $D_{\text {EST }}$ was linearised in order to unbind it from a maximum of 1 by using the following formula: linearised $D_{\mathrm{EST}}=$ $D_{\mathrm{EST}} /\left(1-D_{\mathrm{EST}}\right)$ (Slatkin 1995 , as applied to $\left.F_{\mathrm{ST}}\right)$. Since it is not possible to linearise a $D_{\mathrm{EST}}$ of 1 , in such instances the value of $D_{\mathrm{EST}}$ was reduced to $D_{\mathrm{EST}}=0.999$ before linearisation. Population-pairwise geographic distances were generated using a Geographic Distance Matrix Generator (http://biodiversityinformatics.amnh.org/open_source/gdmg/). The significance of the IBD relationship was assessed by performing 999 permutations of data within the matrices.

\section{Results}

\section{Genetic diversity}

As some loci showed clear evidence for null alleles in some populations we undertook sensitivity analyses removing different loci and/or populations (Table 4 in online supplementary material). The global picture on genetic diversity and differentiation results was very similar between the different datasets and the results are therefore presented with two of the seven loci removed (MsJ32 and MsT12) to maximise the representation of M. sylvaticum populations.

The five microsatellite loci used in the study were all polymorphic, $P=1$. The number of alleles per locus ranged from $A_{\mathrm{N}}=14-24$, and the allelic richness ranged from $A_{\mathrm{R}}=9.19-15.14$ (Table 2 ). Expected heterozygosity ranged from $H_{\mathrm{E}}=0.680-0.923$, whilst the observed heterozygosity was much lower, ranging from $H_{\mathrm{O}}=0.030-0.043$.

Populations in the UK had significantly lower withinpopulation diversity than populations in Scandinavia for the proportion of polymorphic loci $(P)(\mathrm{P}<0.05)$, number 
of alleles per locus $\left(A_{\mathrm{N}}\right)(\mathrm{P}<0.001)$, allelic richness $\left(A_{\mathrm{R}}\right)$ $(\mathrm{P}<0.01)$, proportion of distinguishable genotypes $\left(P_{\mathrm{D}}\right)$ $(\mathrm{P}<0.001)$, expected heterozygosity $\left(H_{\mathrm{E}}\right)(\mathrm{P}<0.01)$ and observed heterozygosity $\left(H_{\mathrm{O}}\right)(\mathrm{P}<0.01)$ (Table 3$)$. Populations in the UK had a lower number of private alleles than populations in Scandinavia but the difference was not significant (UK $A_{\mathrm{P}}=1.0, \quad$ Scandinavia $A_{\mathrm{P}}=2.1$, $\mathrm{P}=0.081$ ) (Table 3).

Seven of the ten UK populations: GT, KB, LS, CR, AT, Mar and RNV; and the Scandinavian population ST had very low amounts of genetic diversity $\left(P=0-0.8 ; A_{\mathrm{N}}=5\right.$ 9; $A_{\mathrm{R}}=1-1.8 ; P_{\mathrm{D}}=0.03-0.46 ; H_{\mathrm{E}}=0-0.182$ ) (Table 3). One population (GT) was monomorphic at all five loci, and three others (RNV, AT and $\mathrm{KB}$ ) were monomorphic at four loci. These populations covered the smallest areas $\left(3-10 \mathrm{~m}^{2}\right.$ for the UK populations; $69 \mathrm{~m}^{2}$ for ST) and had the smallest census sizes (30-150 plants in the UK populations; 2000-5000 in ST) (Table 1). The one exception to this is GT, a UK population with a large census size $(n=8,000)$, but still a very small population area $\left(10 \mathrm{~m}^{2}\right)$.

The remaining three UK populations: $\mathrm{AB}, \mathrm{ER}$ and LO; and the Scandinavian population $\mathrm{RK}$ had intermediate amounts of genetic diversity $\left(P=0.8-1 ; A_{\mathrm{N}}=17-25\right.$; $\left.A_{\mathrm{R}}=3.3-5 ; \quad P_{\mathrm{D}}=0.28-0.93 ; \quad H_{\mathrm{E}}=0.411-0.582\right)$ (Table 3). These three UK populations were the ones with the largest areas in the UK $\left(28 \mathrm{~m}^{2}-64 \mathrm{~m}^{2}\right)$ and had the largest census sizes after GT (1200-1700 plants). Population RK was the Scandinavian population with the second smallest area $\left(96 \mathrm{~m}^{2}\right)$ after ST and the smallest census size (2000-5000 plants) (Table 1).

The remaining six Scandinavian populations: MR, RH, JD, KR, SK and FS had the highest amounts of genetic diversity $\left(P=1 ; \quad A_{\mathrm{N}}=30-41 ; \quad A_{\mathrm{R}}=5.8-7.6 ; \quad P_{\mathrm{D}}=0.71-1 ;\right.$ $\left.H_{\mathrm{E}}=0.600-0.764\right)($ Table 3$)$. These populations covered the largest areas $\left(125-381 \mathrm{~m}^{2}\right)$ and had the largest census sizes (5000->10,000 plants) (Table 1).

The genetic diversity parameters of allelic richness and expected heterozygosity were significantly, positively associated with sampling area $\left(\mathrm{m}^{2}\right)$ across all eighteen populations $\left(A_{\mathrm{R}}: \mathrm{r}=0.795, \mathrm{P}<0.001 ; H_{\mathrm{E}}: \mathrm{r}=0.742\right.$, $\mathrm{P}<0.001)$ and across the ten $\mathrm{UK}$ populations $\left(A_{\mathrm{R}}\right.$ : $\left.\mathrm{r}=0.975, \mathrm{P}<0.001 ; H_{\mathrm{E}}: \mathrm{r}=0.923, \mathrm{P}<0.001\right)$, but not across the eight Scandinavian populations $\left(A_{\mathrm{R}}: \mathrm{r}=0.560\right.$, $\mathrm{P}=0.149 ; H_{\mathrm{E}}: \mathrm{r}=0.504, \mathrm{P}=0.203$ ) (Fig. 1).

At the population level the inbreeding coefficients was very high, ranging from $F_{\text {IS }}=0.849-0.931$, and there was no significant difference between the regions (UK $F_{\mathrm{IS}}=0.925$, Scandinavia $F_{\text {IS }}=0.887, \mathrm{P}=0.374$ ) (Table 3).

\section{Genetic structure}

Genetic differentiation, as estimated by $F_{\mathrm{ST}}$ showed very high global population structure $\left(F_{\mathrm{ST}}=0.554\right)$ and this was significantly higher amongst $\mathrm{UK}$ populations $\left(F_{\mathrm{ST}}=0.749\right)$ than amongst Scandinavian populations $\left(F_{\mathrm{ST}}=0.326\right) \quad(\mathrm{P}<0.01)$. Similarly, the global standardised measure of genetic differentiation, $F^{\prime}{ }_{\text {sT }}$, was very high $\left(F^{\prime}{ }_{\text {ST }}=0.892\right)$ and significantly higher amongst UK populations $\left(F^{\prime}{ }_{\text {ST }}=0.949\right)$ than amongst Scandinavian populations $\quad\left(F^{\prime}{ }_{\mathrm{ST}}=0.762\right) \quad(\mathrm{P}<0.01)$. Population genetic differentiation as estimated by $D_{\mathrm{EST}}$, was very high globally $\left(D_{\mathrm{EST}}=0.773\right)$ but there was no significant difference between populations in the UK $\left(D_{\mathrm{EST}}=0.796\right) \quad$ or $\quad$ in $\quad$ Scandinavia $\quad\left(D_{\mathrm{EST}}=0.689\right)$ $(\mathrm{P}=0.081)$.

There was no correlation between genetic and geographic distance at the inter-population level in either region (UK: $R^{2}=0.010, \quad P=0.274 ; \quad$ Scandinavia: $\left.\mathrm{R}^{2}=0.000, \mathrm{P}=0.460\right)$. Population pairwise genetic differentiation ranged from $D_{\mathrm{EST}}=0.089-1$ (Table 5 in online supplementary material). The two populations with the lowest pairwise differentiation of $D_{\mathrm{EST}}=0.089$ were two Scandinavian populations MR and KR, separated by $3 \mathrm{~km}$. Total genetic differentiation of $D_{\mathrm{EST}}=1$ occurred for thirteen population pairwise combinations, separated
Table 2 Genetic diversity at seven microsatellite loci in Melampyrum sylvaticum from the UK and Scandinavia

\begin{tabular}{lllllllllll}
\hline Locus & $n$ & $\%$ Missing data & $A_{\mathrm{N}}$ & $A_{\mathrm{R}}$ & $H_{\mathrm{E}}$ & $H_{\mathrm{O}}$ & $F_{\mathrm{IS}}$ & $D_{\mathrm{EST}}$ & $F_{\mathrm{ST}}$ & $F^{\prime}{ }_{\mathrm{ST}}$ \\
\hline MsH14 & 500 & 1.57 & 18 & 11.58 & 0.858 & 0.038 & 0.889 & 0.824 & 0.617 & 0.931 \\
MsO66 & 507 & 0.20 & 14 & 9.19 & 0.767 & 0.043 & 0.849 & 0.707 & 0.639 & 0.890 \\
MsQ84 & 505 & 0.59 & 18 & 13.39 & 0.921 & 0.030 & 0.931 & 0.922 & 0.550 & 0.958 \\
MsU21 & 508 & 0 & 21 & 15.14 & 0.923 & 0.039 & 0.928 & 0.887 & 0.419 & 0.923 \\
MsV32 & 505 & 0.59 & 24 & 10.27 & 0.680 & 0.044 & 0.858 & 0.596 & 0.563 & 0.808 \\
MsJ32* & 472 & 1.26 & 3 & 2.19 & 0.454 & 0.004 & 0.955 & 0.419 & 0.803 & 0.886 \\
MsT12* & 220 & 7.56 & 9 & 8.12 & 0.859 & 0.005 & 0.975 & 0.915 & 0.805 & 0.988 \\
\hline
\end{tabular}

$n$, number of samples successfully amplified and scored; $A_{\mathrm{N}}$, number of alleles per locus; $A_{\mathrm{R}}$, allelic richness, the average number of alleles per locus; $H_{\mathrm{E}}$, unbiased expected heterozygosity; $H_{\mathrm{O}}$, observed heterozygosity; $F_{\mathrm{IS}}$, inbreeding coefficient; $D_{\mathrm{EST}}$, estimator of allelic population differentiation; $F_{\mathrm{ST}}$, estimator of population differentiation; $F^{\prime}{ }_{\mathrm{ST}}$, standardised estimator of population differentiation. ${ }^{*}$ Loci with population-wide null alleles and therefore removed from further analyses 
Table 3 Genetic diversity of Melampyrum sylvaticum from the UK and Scandinavia at the population, regional (UK and Scandinavia) and global (all populations) level, using five microsatellite loci

\begin{tabular}{|c|c|c|c|c|c|c|c|c|c|}
\hline Population & $n$ & $P$ & $A_{\mathrm{N}}$ & $A_{\mathrm{R}}$ & $A_{\mathrm{P}}$ & $P_{\mathrm{D}}$ & $H_{\mathrm{E}}$ & $H_{\mathrm{O}}$ & $F_{\text {IS }}$ \\
\hline \multicolumn{10}{|l|}{ UK } \\
\hline $\mathrm{AB}$ & 30 & 0.8 & 17 & 3.3 & 1 & 0.56 & 0.411 & 0.042 & $0.899 * * *$ \\
\hline GT & 30 & 0 & 5 & 1.0 & 1 & 0.03 & 0 & 0 & NA \\
\hline $\mathrm{KB}$ & 30 & 0.2 & 6 & 1.2 & 0 & 0.07 & 0.102 & 0 & $1 * * *$ \\
\hline LS & 30 & 0.8 & 9 & 1.7 & 1 & 0.20 & 0.182 & 0.013 & $0.927 * * *$ \\
\hline $\mathrm{CR}$ & 11 & 0.6 & 9 & NA & 1 & 0.46 & 0.131 & 0.036 & $0.722^{* *}$ \\
\hline ER & 30 & 1.0 & 20 & 3.9 & 1 & 0.28 & 0.428 & 0.020 & $0.953 * * *$ \\
\hline AT & 24 & 0.2 & 6 & 1.2 & 1 & 0.08 & 0.017 & 0 & $1 *$ \\
\hline Mar & 24 & 0.6 & 9 & 1.8 & 0 & 0.17 & 0.162 & 0 & $1 * * *$ \\
\hline RNV & 29 & 0.2 & 6 & 1.2 & 0 & 0.07 & 0.007 & 0.007 & NA \\
\hline LO & 30 & 1.0 & 26 & 5.0 & 4 & 0.77 & 0.582 & 0.047 & $0.920 * * *$ \\
\hline \multicolumn{10}{|l|}{ Scandinavia } \\
\hline MR & 30 & 1.0 & 30 & 5.9 & 0 & 0.7 & 0.607 & 0.020 & $0.967 * * *$ \\
\hline $\mathrm{RH}$ & 30 & 1.0 & 41 & 8.0 & 2 & 1 & 0.764 & 0.161 & $0.789 * * *$ \\
\hline JD & 30 & 1.0 & 31 & 6.1 & 2 & 0.93 & 0.637 & 0.034 & $0.947 * * *$ \\
\hline ST & 30 & 0.4 & 7 & 1.4 & 1 & 0.10 & 0.032 & 0.007 & $0.794 * *$ \\
\hline $\mathrm{KR}$ & 30 & 1.0 & 30 & 5.8 & 1 & 1 & 0.600 & 0.087 & $0.854 * * *$ \\
\hline $\mathrm{RK}$ & 30 & 1.0 & 25 & 4.9 & 5 & 0.93 & 0.506 & 0.100 & $0.802 * * *$ \\
\hline SK & 30 & 1.0 & 38 & 7.4 & 4 & 1 & 0.741 & 0.040 & $0.946 * * *$ \\
\hline FS & 30 & 1.0 & 39 & 7.6 & 6 & 0.90 & 0.691 & 0.067 & $0.904 * * *$ \\
\hline \multicolumn{10}{|c|}{ Regional average } \\
\hline UK & $26.8 \mathrm{~ns}$ & $0.5^{*}$ & $11.3^{* * *}$ & $2.3 * *$ & $1 \mathrm{~ns}$ & $0.37 * *$ & $0.199 * *$ & $0.016^{* *}$ & $0.925 \mathrm{~ns}$ \\
\hline Scandinavia & 30.0 & 0.9 & 30.1 & 5.9 & 2.1 & 0.81 & 0.564 & 0.064 & 0.887 \\
\hline Global average & 28.2 & 0.7 & 20.0 & 4.0 & 1.7 & 0.58 & 0.361 & 0.038 & 0.899 \\
\hline
\end{tabular}

$n$, sample size; $P$, proportion of polymorphic loci; $A_{\mathrm{N}}$, the total number of alleles over five loci; $A_{\mathrm{R}}$, allelic richness over five loci, rarefied to a sample size of 24 individuals; $A_{\mathrm{P}}$, private alleles; $P_{\mathrm{D}}$, proportion of distinguishable genotypes; $H_{\mathrm{E}}$, unbiased expected heterozygosity; $H_{\mathrm{O}}$, observed heterozygosity; $F_{\mathrm{IS}}$, inbreeding coefficient. Significance levels: $* * *=\mathrm{P}<0.001$; $* *=\mathrm{P}<0.01$, $*=\mathrm{P}<0.05$; ns not significantly different from zero; $N A$ not applicable
Fig. 1 Correlation between (a) allelic richness $\left(A_{\mathrm{R}}\right)$ and (b) expected heterozygosity $\left(H_{\mathrm{E}}\right)$, with sampling area $\left(\mathrm{m}^{2}\right)$ for Scandinavian (SC) and UK populations of Melampyrum sylvaticum

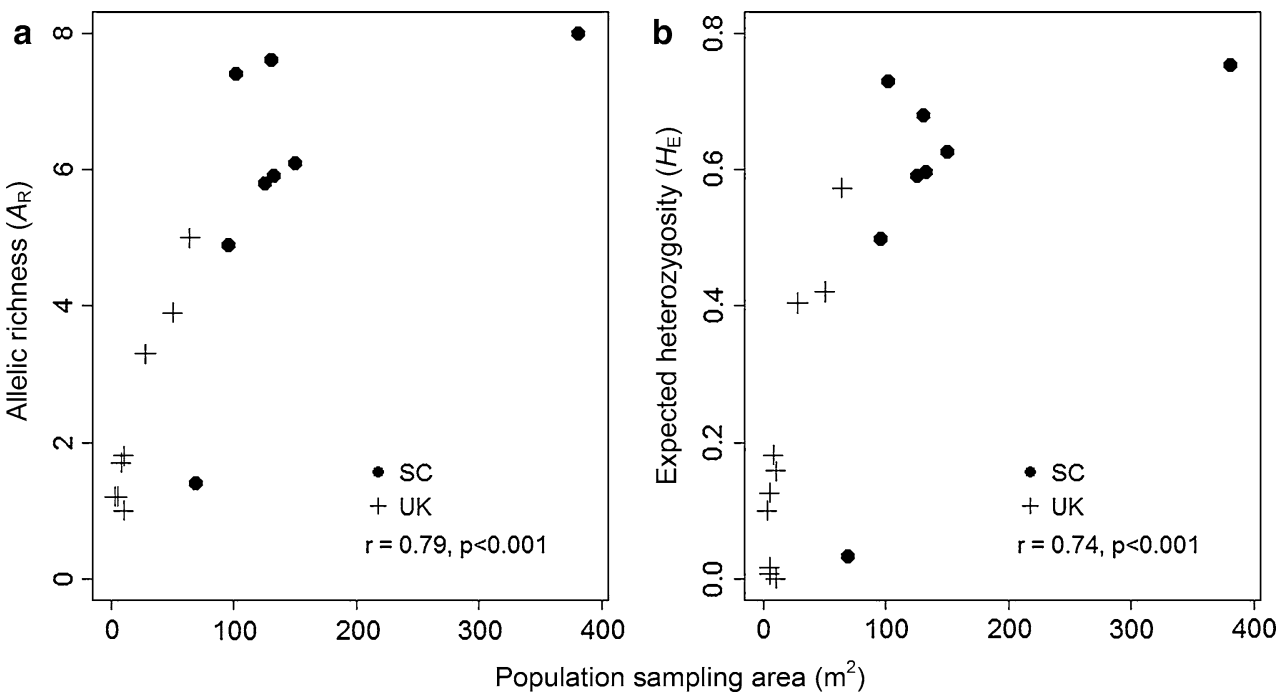

by distances ranging from $1 \mathrm{~km}$ (between UK populations ER and AT, located in different gullies of the same mountain) to $1739 \mathrm{~km}$ (between UK population AT and
Scandinavian population ST, both with very low amounts of genetic diversity) (Table 5 in online supplementary material). 


\section{Discussion}

This research was initiated to gain a greater understanding of the biology of the annual, hemiparasitic plant species $M$. sylvaticum that is endangered in the UK in order to design a species-specific conservation management plan with the best chance of long-term success.

A key result of this study is that $M$. sylvaticum is highly inbreeding irrespective of population demographic or habitat factors. The inbreeding coefficients for $M$. sylvaticum populations ( $\left.F_{\mathrm{IS}}=0.722-1\right)$ are amongst the highest, and least variable of any species within the Rhinanthoid Orobanchaceae clade (sensu Těšitel et al. 2010): Euphrasia spp. $F_{\mathrm{IS}}=0.17-0.77$ (French et al. 2005), Rhinanthus minor $F_{\mathrm{IS}}=0-0.852$ (Ducarme and Wesselingh 2013; Houston and Wolff 2012), and Rhinanthus angustifolius $F_{\mathrm{IS}}=0-0.169$ (Ducarme and Wesselingh 2013). Whilst it was known that M. sylvaticum was able to set seed in the absence of pollinators (Molau 1993; Dalrymple 2006), this was presumed to occur primarily as a reproductive back-up strategy for when cross-pollination had not occurred (Smith 1963; Horrill 1972; Kwak 1988).

That M. sylvaticum is naturally highly inbreeding will have positive consequences for how the species experiences surviving in small, isolated populations (Aguilar et al. 2006, 2008). Most importantly, reproduction will be assured in the absence of conspecifics or pollinator species, and the effects of inbreeding depression are likely to be reduced due to the prior purging of deleterious alleles (Byers and Waller 1999). This may contribute to the persistence of M. sylvaticum in some of the small, isolated habitat fragments. However, the predominantly selfing breeding system will also restrict levels of gene flow in $M$. sylvaticum populations which might be exacerbated by limited seed dispersal (Dalrymple 2007). The seeds of $M$. sylvaticum are the largest within the Orobanchaceae (Těšitel et al. 2010) and are unlikely to exceed the dispersal distances of closely related $M$. pratense where the average distance is $0.91 \mathrm{~m} /$ year and the majority of seeds disperse within $0.25 \mathrm{~m}$ of the mother plant (Heinken 2004). It is therefore not surprising that the studied populations show high levels of genetic differentiation (UK: $F^{\prime}{ }_{\mathrm{ST}}=0.949$, and Scandinavia: $F^{\prime}{ }_{\mathrm{ST}}=0.762$ ).

A general finding from this study is that populations occupying small patches of habitat have low genetic diversity. This is the case for most UK populations, and the one Scandinavian population (ST) with a similar population area to those from the UK also had lower genetic diversity. The most diverse population from the UK (LO) was the one occupying the largest area, and the large populations in Scandinavia typically showed high levels of genetic diversity. The six largest Scandinavian populations had the highest amount of genetic diversity and were within large areas of natural woodland and did not have clear boundaries. Genetic diversity was so high that the majority of the plants sampled contained a unique multilocus genotype. This is in agreement with findings from other studies where a continuous habitat relatively free from anthropogenic disturbances tended to contain more genetic, species and functional diversity than small and isolated habitat patches (MacArthur and Wilson 1967; Lovejoy et al. 1986; Saunders et al. 1991; Tabarelli et al. 1999; Flynn et al. 2009).

\section{Conservation management implications}

In light of these findings we recommend that as many of the UK populations as possible, including the smallest populations which have been historically been overlooked (Centre for Plant Conservation 1991; Dalrymple and Broome 2010), are conserved, ideally in situ but also ex situ, because each population is likely to contain unique genetic (and potentially functional phenotypic) diversity. Whilst much of the within-population genetic diversity will be 'epitypic' due to genetic drift, some may be 'ecotypic' due to natural selection to the local ecological and environmental conditions (Hufford and Mazer 2003; Picó and van Groenendael 2007).

Given the strong relationship between population area and genetic diversity, it is particularly important for this species that seed collected for conservation activities is collected from as many mothers as possible spread across the site, over a number of successive years. This strategy would ensure that much of the genetic diversity within a population is captured (Kettle et al. 2008; Weeks et al. 2011), and would lessen the seed-collection burden from the wild populations in any one year (Centre for Plant Conservation 1991; McKay et al. 2005). The collected seed could be sown into an ex situ environment and maintained as a living collection (Crichton et al. 2012) with the seeds produced being used to continue the living collection and for restoration efforts, in line with Target 8 of the Global Strategy for Plant Conservation: "At least $75 \%$ of threatened plant species in ex situ collections, preferably in the country of origin, and at least $20 \%$ available for recovery and restoration programmes" (www.plants2020. net/target-8).

Where there is suitable habitat near to an extant population, local expansion should be performed by humanmediated seed dispersal. This would increase the population area and number of individuals; capture as much of the genetic diversity contained within the extant population as possible and therefore slow down the effects of genetic 
drift; and increase the opportunity for novel diversity to evolve. Local population expansion has already been effectively performed at the $\mathrm{AB}$ and GT populations with good results (Dalrymple 2006; Andy Scobie, pers. comm. Cairngorms Rare Plants Project, 2012).

Translocation of seed into new sites has been performed with limited success and it is difficult to know the reasons for this (Dalrymple and Broome 2010). When material is selected for translocations, ecological similarity between donor and receipt sites is a pragmatic starting point (Montalvo and Ellstrand 2000; Joshi et al. 2001; Bischoff et al. 2006; Noël et al. 2011). The highly selfing nature of the species means that the probability of persistent outbreeding depression resulting from translocations is low because even if genetically incompatible lineages are brought together, the chances of crossing events are limited. This provides an opportunity to experiment with using seed from multiple genetically differentiated populations, thereby maximizing the chances of some material being adapted to the prevailing conditions of the new site and so surviving in the short term, and of having adequate genetic diversity to respond to future environmental change in the longer term.

Acknowledgments The authors wish to thank all landowners for permission to sample to populations; J. Squirrell, J. Droop, C. Horsfall, S. Aeschlimann, E. Crothall for fieldwork assistance; J. Squirrell, A. Forrest and M. Ruhsam for laboratory assistance; M. Ruhsam, A. Jump and A. Taylor for comments on an earlier version of this manuscript. RJC was supported by a Natural Environment Research Council studentship, a Scottish Natural Heritage Grant and an EU ATANS Grant (Fp6 506004) for travel and fieldwork expenses at the Abisko Scientific Research Station. The Royal Botanic Garden Edinburgh is supported by the Scottish Government's Rural and Environment Science and Analytical Services Division.

\section{Compliance with ethical standards}

Conflict of interest The authors declare that they have no conflict of interest.

Open Access This article is distributed under the terms of the Creative Commons Attribution 4.0 International License (http://crea tivecommons.org/licenses/by/4.0/), which permits unrestricted use, distribution, and reproduction in any medium, provided you give appropriate credit to the original author(s) and the source, provide a link to the Creative Commons license, and indicate if changes were made.

\section{References}

Aguilar R, Ashworth L, Galetto L, Aizen MA (2006) Plant reproductive susceptibility to habitat fragmentation: review and synthesis through a meta-analysis. Ecol Lett 9:968-980

Aguilar R, Quesada M, Ashworth L, Herrerias-Diego Y, Lobo J (2008) Genetic consequences of habitat fragmentation in plant populations: susceptible signals in plant traits and methodological approaches. Mol Ecol 17:5177-5188
Baddeley A, Turner R (2005) Spatstat: an R package for analyzing spatial point patterns. J Stat Softw 12:1-42

Bekker RM, Kwak MM (2005) Life history traits as predictors of plant rarity, with particular reference to hemiparasitic Orobanchaceae. Folia Geobot 40:231-242

Bischoff A, Crémieux L, Smilauerova M, Lawson CS, Mortimer SR, Dolezal J, Lanta V, Edwards AR, Brook AJ, Macel M, Leps J, Steinger T, Müller-Schärer H (2006) Detecting local adaptation in widespread grassland species-the importance of scale and local plant community. J Ecol 94:1130-1142

Busch JW (2005) Inbreeding depression in self-incompatible and selfcompatible populations of Leavenworthia alabamica. Heredity 94:159-165

Byers DL, Waller SM (1999) Do plant populations purge their genetic load? Effects of population size and mating history on inbreeding depression. Annu Rev Ecol Syst 30:479-513

Centre for Plant Conservation (1991) Genetic sampling guidelines for conservation collections of endangered plants. In: Falk DA, Holsinger KE (eds) Genetics and conservation of rare plants. Oxford University Press, New York, pp 225-239

Charlesworth D, Willis JH (2009) The genetics of inbreeding depression. Nat Rev Genet 10:783-796

Cheffings C, Farrell L (2005) The vascular plant red data list for Great Britain. Joint Nature Conservation Committee, Peterborough

Crawford N (2010) SMOGD: software for the measurement of genetic diversity. Mol Ecol Resour 10:556-557

Crichton RJ, Dalrymple SE, Hollingsworth PM (2012a) Horticultural protocols to aid the conservation of Melampyrum sylvaticum, Orobanchaceae (small cow-wheat), an endangered hemiparasitic plant. Sibbaldia J Bot Garden Hortic 10:57-69

Crichton RJ, Squirrell J, Woodin SJ, Dalrymple SE, Hollingsworth PW (2012b) Isolation of microsatellite primers for Melampyrum sylvaticum (Orobanchaceae), an endangered plant in the United Kingdom. Am J Bot 99:e457-e459

Dalrymple SE (2006) Rarity and conservation of Melampyrum sylvaticum. Ph.D. thesis. University of Aberdeen, Aberdeen, UK

Dalrymple SE (2007) Biological flora of the British Isles: Melampyrum sylvaticum L. J Ecol 95:585-597

Dalrymple SE, Broome A (2010) The importance of donor population identity and habitat type when creating new populations of small cow-wheat Melampyrum sylvaticum from seed in Perthshire, Scotland. Conserv Evid 7:1-8

Doyle JJ, Doyle JL (1990) Isolation of plant DNA from fresh tissue. Focus 12:13-15

Ducarme V, Wesselingh RA (2013) Outcrossing rates in two selfcompatible, hybridizing Rhinanthus species: implications for hybrid formation. Plant Biol 15:541-547

Duminil J, Fineschi S, Hampe A, Jordano P, Salvini D, Vendramin GG, Petit RJ (2007) Can population genetic structure be predicted from life-history traits. Am Nat 169:662-672

Edmands S (2007) Between a rock and a hard place: evaluating the relative risks of inbreeding and outbreeding for conservation management. Mol Ecol 16:463-475

Flynn DFB, Gogol-Prokurat M, Nogeire T, Molinari N, Trautman Richers B, Lin BB, Simpson N, Mayfield MM, DeClerck F (2009) Loss of functional diversity under land use intensification across multiple taxa. Ecol Lett 12:22-33

Frankham R, Ballou JD, Briscoe DA (2002) Introduction to conservation genetics. Cambridge University Press, Cambridge

French GC, Ennos RA, Silverside AJ, Hollingsworth PM (2005) The relationship between flower size, inbreeding coefficient and inferred selfing rate in British Euphrasia species. Heredity 94:44-51

Gilpin ME, Soulé ME (1986) Minimum viable populationsprocesses of extinction. In: Soulé ME (ed) Conservation biology: the science of scarcity and diversity. Sinauer Associates, Sunderland, pp 19-34 
Goudet J (1995) FSTAT (version 1.2): a computer program to calculate F-statistics. J Hered 86:485-486

Hamrick JL, Godt MJW (1996) Effects of life history traits on genetic diversity in plant species. Philos Trans R Soc Lond B 351:1291-1298

Hedrick PW (2005) A standardized genetic differentiation measure. Evolution 59:1633-1638

Heinken T (2004) Migration of an annual myrmecochore: a four year experiment with Melampyrum pratense L. Plant Ecol 170:55-72

Horrill AD (1972) Melampyrum cristatum L. J Ecol 60:235-244

Houston K, Wolff K (2012) Rhinanthus minor population genetic structure and subspecies: potential seed sources of a keystone species in grassland restoration projects. Perspect Plant Ecol Evol Syst 14:423-433

Hufford KM, Mazer SJ (2003) Plant ecotypes: genetic differentiation in the age of ecological restoration. Trends Ecol Evol 18:147-155

Husband BC, Schemske DW (1996) Evolution of the magnitude and timing of inbreeding depression in plants. Evolution 50:54-70

Jolivet C, Rogge M, Degen B (2013) Molecular and quantitative signatures of biparental inbreeding depression in the selfincompatible tree species Prunus avium. Heredity 110:439-448

Joshi J, Schmid B, Caldeira MC, Dimitrakopoulos PG, Good J, Harris R, Hector A, Huss-Danell K, Jumpponen A, Minns A, Mulder CPH, Pereira JS, Prinz A, Scherer-Lorenzen M, Siamantziouras ASD, Terry AC, Troumbis AY, Lawton JH (2001) Local adaptation enhances performance of common plant species. Ecol Lett 4:536-544

Jost L (2008) GST and its relatives do not measure differentiation. Mol Ecol 17:4015-4026

Kettle CJ, Ennos RA, Jaffré T, Gardner M, Hollingsworth PM (2008) Cryptic genetic bottlenecks during restoration of an endangered tropical conifer. Biol Conserv 141:1953-1961

Kramer AT, Havens K (2009) Plant conservation genetics in a changing world. Trends Plant Sci 14:599-607

Kwak MM (1988) Pollination ecology and seed-set in the rare annual species Melampyrum arvense L. (Scrophulariaceae). Acta Botanica Neerlandica 37:153-163

Lande R (1988) Genetics and demography in biological conservation. Science 241:1455-1460

Lewis PO, Zaykin D (2001) Genetic data analysis: computer program for the analysis of alleleic data. Release 1.0. Department of Ecology and Evolution, University of Connecticut

Lovejoy TE, Bierregaard RO Jr, Rylands AB, Malcolm JR, Quintela CE, Harper LH, Brown KS Jr, Powell AH, Powell GVN, Schubart HOR, Hays M (1986) Edge and other effects of isolation on Amazon forest fragments. In: Soulé ME (ed) Conservation biology. The Science of Scarcity and Diversity, Sinauer Associates, pp 257-285

MacArthur RH, Wilson EO (1967) The theory of island biogeography. Princeton University Press, Princeton

Matthies D, Bräuer I, Maibom W, Tscharntke T (2004) Population size and the risk of local extinction: empirical evidence from rare plants. Oikos 105:481-488

McKay JK, Christian CE, Harrison S, Rice KJ (2005) "How local is local?"- a review of practical and conceptual issues in the genetics of restoration. Restor Ecol 13:432-440

Meirmans PG (2006) Using the amova framework to estimate a standardized genetic differentiation measure. Evolution 60:2399-2402

Michalski SG, Durka W (2007) High selfing and high inbreeding depression in peripheral populations of Juncus atratus. Mol Ecol 16:4715-4727

Molau U (1993) Relationships between flowering phenology and life history strategies in tundra plants. Arct Alp Res 25:391-402
Montalvo AM, Ellstrand NE (2000) Transplantation of the subshrub Lotus scoparius: testing the home-site advantage hypothesis. Conserv Biol 14:1034-1045

Murcia C (1995) Edge effects in fragmented forests: implications for conservation. Trends Ecol Evol 10:58-62

Nason JD, Ellstrand NC (1995) Lifetime estimates of biparental inbreeding depression in the self-incompatible annual plant Raphus sativus. Evolution 49:307-316

Neaves LE, Whitlock R, Piertney SR, Burke T, Butlin RK, Hollingsworth PM (2013) Implications of climate change for genetic diversity and evolvability in the UK. Terrestrial biodiversity climate change impacts report card, Technical paper 15. http://lwec.org.uk/sites/default/files/Genetics.pdf

Noël F, Prati D, van Kleunen M, Gygax A, Moser D, Fischer M (2011) Establishment success of 25 rare wetland species introduced into restored habitats is best predicted by ecological distance to source habitats. Biol Conserv 144:602-609

O'Grady JJ, Reed DH, Brook BW, Frankham R (2004) What are the best correlates of predicted extinction risk. Biol Conserv 118:513-520

Peakall R, Smouse PE (2006) GENALEX 6: genetic analysis in excel. Population genetic software for teaching and research. Mol Ecol Notes 6:288-295

Picó FX, van Groenendael J (2007) Large-scale plant conservation in European semi-natural grasslands: a population genetic perspective. Divers Distrib 13:920-926

R Core Development Team. R: A language and environment for statistical computing. R Foundation for Statistical Computing, Vienna. http://www.R-project.org/

Rich TCG, Fitzgerald R, Sydes C (1998) Distribution and ecology of small cow-wheat (Melampyrum sylvaticum L., Scrophulariaceae) in the British Isles. Bot J Scotl 50:29-46

Rouselle Y, Thomas M, Galic N, Bonnin I, Gildringer I (2011) Inbreeding depression and low between-population heterosis in recently diverged experimental populations of a selfing species. Heredity 106:289-299

Rumsey FJ (1994) Melampyrum sylvaticum L. In: Stewart A, Pearman DA, Preston CD (eds) Scarce plants in Britain. Joint Nature Conservation Committee, Peterborough, p 262

Saunders DA, Hobbs RJ, Margules CR (1991) Biological consequences of ecosystem fragmentation: a review. Conserv Biol 5:18-32

Schaal BA, Leverich WJ (1996) Molecular variation in isolated plant populations. Plant Species Biol 11:33-40

Scottish Natural Heritage (2007) a five year species action framework: making a difference for Scotland's species. Scottish Natural Heritage Publications, Battleby

Slatkin M (1995) A measure of population subdivision based on microsatellite allele frequencies. Genetics 139:457-462

Smith AJD (1963) Variation in Melampyrum pratense L. Watsonia 5:336-367

Soó RD, Webb DA (1972) Melampyrum L. In: Tutin TG, Heywood VH, Burges NA, Moore DM, Valentine DH, Walters SM (eds) Flora Europaea, vol 3. Cambridge University Press, Cambridge, pp 253-257

Spielman D, Brook BW, Frankham R (2004) Most species are not driven to extinction before genetic factors impact them. Proc Natl Acad Sci 101:15261-15264

Tabarelli M, Mantovani W, Peres CA (1999) Effects of habitat fragmentation on plant guild structure in the montane Atlantic forest of southeastern Brazil. Biol Conserv 91:119-127

Teixeira S, Foerster K, Bernasconi G (2009) Evidence for inbreeding depression and post-pollination selection against inbreeding in the dioecious plant Silene latifolia. Heredity 102:101-112

Tennant DJ (2008) Small cow-wheat Melampyrum sylvaticum L.; Scrophulariaceae in England. Watsonia 27:23-36 
Těšitel J (2007) Variation in the Melampyrum sylvaticum group. MSc thesis. University of České Budějovice, České Budějovice, Czech Republic

Těšitel J, Ŕíha P, Svobodov Š, Malinov T, Štech M (2010) Phylogeny, life history evolution and biogeography of the Rhinanthoid Orobanchaceae. Folia Geobot 45:347-367

Weeks AR, Sgro CM, Breed MF, James EA, Hoffman AA, Young AG, Frankham R, Mitchell NJ, Miller KA, Bryne M, Coates DJ, Eldridge MDB, Sunnucks P (2011) Assessing the benefits and risks of translocations in changing environments: a genetic perspective. Evol Appl 4:709-725
Weir BS, Cockerham CC (1984) Estimating F-statistics for the analysis of population structure. Evolution 38:1358-1370

Wotton DM, Kelly D (2011) Frugivore loss limits recruitment of large-seeded trees. Proc Royal Soc London Ser B 278:3345-3354

Young A, Boyle T, Brown T (1996) The population genetic consequences of habitat fragmentation for plants. Trends Ecol Evol 11:413-418

UK Biodiversity Group. 1999. Tranche 2 action plans_-volume III: Plants and fungi. Joint Nature Conservation Committee, Peterborough 